\title{
HUBUNGAN PENGETAHUAN DENGAN KETERAMPILAN PERAWAT DAN DOKTER DALAM PENATALAKSANAAN PRIMARY SURVEY PADA PASIEN PENURUNAN KESADARAN DI IGD RS SILOAM SRIWIJAYA PALEMBANG TAHUN 2018
}

\section{THE CORRELATION BETWEEN KNOWLEDGE AND SKILL OF NURSES AND DOCTORS IN THE PRIMARY SURVEY MANAGEMENT IN PATIENTS DECREASING AWARENESS AT EMERGENCY DEPARTMENT SILOAM SRIWIJAYA HOSPITAL PALEMBANG 2018}

\author{
Oleh : \\ Sri Hartati ${ }^{1,}$ Shinta Maharani ${ }^{2}$ \\ ${ }^{1}$ Prodi Kebidanan, Stik Siti Khadijah Palembang \\ ${ }^{2}$ Prodi S1 keperawatan, STIK Siti Khadijah Palembang \\ Email : ayi_ins@yahoo.com
}

\begin{abstract}
ABSRTRACT
Patients management with reduced awareness, requires rapid assessment and appropriate measures to avoid death and disability by managing initial assumptions that include: primary survey (ABCDE), secondary survey (Head To Toe examination), continuous re-evaluation, and definitive therapy. This study was quantitative and used cross-sectional design, with total sample was 32 respondents. The results in this study showed that level of knowledge of respondents in the good category was 19 respondents $(59,5 \%)$, and skills of respondents in the skilled category was 25 respondents $(78,1 \%)$. Statistical analysis were analyzed by Fisher Test and showed that significance value was $0,01(p<0,05)$. The conclusion of this study there was significant correlation between knowledge and skills of nurses and doctors in the primary survey management in patients decreasing awareness at Emergency Department Siloam Sriwijaya Hospital Palembang 2018. This study could be useful to provide information about correlation between knowledge and skills of nurses and doctors in the primary survey management in patients decreasing awareness at Emergency Department Siloam Sriwijaya Hospital Palembang 2018.
\end{abstract}

Keywords : Knowledge, Skill, Primary Survey

\begin{abstract}
ABSTRAK
Pengelolaan pasien dengan penurunan kesadaran memerlukan penilaian cepat dan tindakan tepat untuk menghindari kematian dan kecacatan dengan penatalaksanaan initial assement (penilaian awal) yang meliputi : primary survey (ABCDE), secondary survey (pemeriksaan Head To Toe), reevaluasi berkesinambungan dan terapi definitive. Jenis penelitian kuantitatif dengan pendekatan cross sectional. Teknik pengambilan sampel yang digunakan adalah total sampling dengan jumlah sampel sebanyak 32 responden. Hasil dalam penelitian ini menunjukkan tingkat pengetahuan perawat dan dokter dalam kategori baik yaitu 19 (59,5\%), dan hasil keterampilan perawat dan dokter dalam kategori terampil yaitu $25(78,1 \%)$. Berdasarkan uji statistik menggunakan alternatif uji Fisher menunjukkan nilai signifikansi sebesar $0,01(p \leq 0,05)$. Dengan demikian dapat disimpulkan bahwa ada hubungan bermakna antara pengetahuan dengan keterampilan perawat dan dokter dalam penatalaksanaan primary survey pada pasien dengan penurunan kesadaran di IGD RS Siloam Sriwijaya Palembang. Diharapkan penelitian ini dapat bermanfaat untuk memberikan informasi tentang hubungan pengetahuan dan keterampilan perawat dan dokter dalam penatalaksanaan primary survey pada pasienpenurunan kesadaran di IGD.
\end{abstract}

Kata kunci : Hubungan Pengetahuan, Keterampilan, Primary Survey

\section{PENDAHULUAN}

Penurunan kesadaran adalah keadaan dimana penderita tidak sadar dalam arti tidak terjaga / tidak terbangun secara utuh sehingga tidak mampu memberikan respons yang normal terhadap stimulus. Kesadaran secara sederhana dapat dikatakan sebagai keadaan dimana seseorang mengenal atau mengetahui tentang dirinya maupun lingkungannya (Padmosantjojo, 2000) Kejadian penurunan 
kesadaran yang sering dijumpai di IGD adalah kasus stroke dan cidera kepala,berdasarkan data dari NCHS (National Center of Health Statistic). Data tentang penurunan kesadaran yang disebabkan oleh stroke menduduki urutan ketiga penyebab kematian di Amerika setelah penyakit jantung dan kanker baik di negara maju maupun negara berkembang. Satu dari 10 kematian disebabkan oleh stroke (Ennen, 2004; Marsh\&Keyrouz, 2010; (Heart Disease and Stroke Statistic 2010 Update: A Report from American Heart Association). Persentase yang meninggal akibat kejadian stroke pertama kali adalah 18\% $37 \%$ dan $62 \%$ untuk kejadian stroke berulang. Jumlah penderita penyakit stroke di Indonesia tahun 2013, estimasi jumlah terbanyak yaitu 533.895 orang $(16,6 \%)$, sedangkan Provinsi Papua Barat memiliki jumlah penderita paling sedikit yaitu sebanyak 2.955 orang $(5,3 \%)$. Dan di Sumatera Selatan sebanyak 87.676 orang $(16 \%)$, (Sumber: Diolah berdasarkan Data Riset Kesehatan Dasar 2013, Badan Litbangkes Kemenkes RI dan Data Penduduk Sasaran, Pusdatin Kementerian Kesehatan RI.) Data penurunan kesadaran yang diakibatkan oleh cedera kepala menurut WHO memperkirakan pada tahun 2020 kecelakaan lalu lintas akan menjadi salah satu penyebab penyakit dan trauma ketiga paling banyak di dunia. Insiden cedera kepala di Eropa pada tahun 2010 terdapat 500 per 100.000 populasi setiap tahun (Irawan, 2010).Diperkirakan terdapat 1,4 juta kasus cedera kepala, dengan lebih dari 1,1 juta yang datang ke Unit Gawat Darurat (World Health Organization, 2010).

Di Indonesia, cedera kepala berdasarkan hasil Riskesdas 2013 menunjukkan insiden cedera kepala sebanyak 100.000 jiwa meninggal dunia (Kemenkes RI, 2013). Presentasi penyebab cedera karena kecelakaan transportasi darat berdasarkan hasil Riskesdas tahun 2013 terjadi peningkatan yang cukup tinggi, dari tahun sebelumnya $25,9 \%$ menjadi $47,7 \%$ pada tahun 2013.

Berdasarkan data hasil analisis dan evaluasi yang dilakukan Direktorat Lalu-lintas (Ditlantas) Polda Sumsel, jumlah kecelakaan lalu lintas yang terjadi di Sumatera Selatan pada tahun 2016 meningkat sebanyak 30 persen dan kasus cidera kepala mengalami peningkatan 26,6 persen dibandingkan tahun 2015. Pengelolaan pasien dengan penurunan kesadaran memerlukan penilaian cepat dan tindakan tepat untuk menghindari kematian dan kecacatan dengan penatalaksanaan initial aseesment (penilaian awal) yang meliputi : primary survey (ABCDE), secondary survey (pemeriksaan Head To Toe), reevaluasi berkesinambungan dan terapi definitive (ATLS, 2012).

Perilaku merupakan suatu stimulus atau tindakan yang dapat diamati dan hasil pengalaman proses interaksi dengan lingkungannya, yang terwujud dalam bentuk pengetahuan, sikap, dan tindakan / keterampilan. Keterampilan petugas kesehatan IGD sangat dibutuhkan dalam pengambilan keputusan klinis agar tidak terjadi kesalahan dalam melakukan pemilahan pasien (Sary Reny, dkk, 2014). Menurut Notoatmodjo (2010), pengetahuan atau kognitif merupakan domain yang sangat penting untuk terbentuknya tindakan seseorang (over behavior). Berdasarkan data yang diperoleh dari Head Nurse IGD RS Siloam Sriwijaya Palembang jumlah pasien yang dirawat dengan penurunan kesadaran akibat trauma dan non trauma pada bulan Januari 2018 (54 pasien), bulan Februari 2018 (66 pasien) dan bulan Maret 2018 (71 pasien).

Pada survey awal yang dilakukan peneliti di IGD RS Siloam Sriwijaya Palembang pada tanggal 26 April 2018 didapatkan data bahwa jumlah perawat di IGD RS Siloam Sriwijaya Palembang sebanyak 16 orang dan jumlah dokter umum 16 orang, semuanya sudah mengikuti pelatihan BLS dan ACLS. Hasil wawancara dengan 4 orang perawat IGD RS Siloam Sriwijaya ditemukan adanya kesenjangan antara pengetahuan dan jawaban yang diberikan perawat IGD saat diberi pertanyaan tentang primary survey. Hasil penelitian dari peneliti sebelumnya, Zulfiana tahun 2017 yang berjudul faktor-faktor yang berhubungan dengan pengetahuan dokter dan perawat tentang penatalaksanaan primary survey pada pasien penurunan kesadaran di IGD RS Siloam Sriwijaya Palembang Tahun 2017 menyimpulkan bahwa ada hubungan bermakna antara usia, masa kerja, pelatihan dengan pengetahuan.

Berdasarkan latar belakang yang diuraikan tersebut, maka peneliti tertarik untuk melakukan penelitian mengenai hubungan pengetahuan dengan keterampilan perawat dalam penatalaksanaan primary survey pada pasien penurunan kesadaran di IGD RS Siloam Sriwijaya Palembang. 


\section{METODE PENELITIAN}

Penelitian ini merupakan penelitian kuantitatif. Desain penelitian yang akan dilakukan adalah cross sectional yaitu pengumpulan data baik untuk variabel independen dan variabel dependen dilakukan bersama-sama (Notoatmodjo, 2012). Dengan metode ini diharapkan dapat mengetahui hubungan pengetahuan dengan keterampilan perawat dan dokter dalam penatalaksanaan primary survey pada pasien penurunan kesadaran di IGD RS Siloam Sriwijaya Palembang.

\section{HASIL PENELITIAN}

\section{Analisa Univariat}

Hasil analisa univariat dalam penelitian ini digunakan untuk menggambarkan distribusi frekuensi dari variabel independen (pengetahuan tentang primary survey).

\section{Pengetahuan}

Tabel 1 Distribusi frekuensi responden berdasarkan pengetahuan tentang primary survey di IGD RS Siloam Sriwijaya Palembang

\begin{tabular}{|l|l|l|}
\hline \multicolumn{1}{|c|}{ Pengetahuan } & F & \multicolumn{2}{c|}{$\%$} \\
\hline Baik & 19 & 59,4 \\
\hline Kurang Baik & 13 & 40,6 \\
\hline Total & 32 & 100 \\
\hline
\end{tabular}

Berdasarkan tabel 4.1 dari 32 responden yang memiliki pengetahuan baik 19 responden $(59,4 \%)$, lebih banyak dari responden yang memiliki pengetahuan kurang baik didapatkan 13 responden $(40,6 \%)$.

\section{Keterampilan}

Tabel 4 Distribusi frekuensi responden berdasarkan keterampilan tentang primary survey di IGD RS Siloam Sriwijaya Palembang 2018

\begin{tabular}{|l|c|c|}
\hline Keterampilan & $\mathrm{F}$ & $\%$ \\
\hline Terampil & 25 & 78,1 \\
\hline $\begin{array}{l}\text { Cukup } \\
\text { Terampil }\end{array}$ & 7 & 21,9 \\
\hline \multicolumn{1}{|c|}{ Total } & 32 & 100 \\
\hline
\end{tabular}

Berdasarkan tabel 2 dari 32 responden yang terampil sebanyak 25 responden $(78,1 \%)$, lebih banyak daripada responden cukup terampil 7 responden $(21,9 \%)$.

\section{Analisis Bivariat}

Hasil analisis bivariat dalam penelitian ini digunakan untuk membuktikan hubungan antara variabel independen (pengetahuan perawat dan dokter tentang primary survey) dan variabel dependen (keterampilan perawat dan dokter dalam penatalaksanaan primary survey) di IGD RS Siloam Sriwijaya Palembang Tahun 2018. Uji statistik digunakan adalah Chi square dengan derajat kepercayaan $95 \%$ a $<0,05$.

Tabel 3 Hasil uji statistik hubungan pengetahuan dengan ketrampilan dokter dan perawat dalam penatalaksanaan primary survey di IGD RS.

Siloam Sriwijaya Palembang 2018

\begin{tabular}{|l|l|l|l|l|l|}
\hline \multirow{2}{*}{$\begin{array}{l}\text { Penget } \\
\text { ahuan }\end{array}$} & \multicolumn{4}{|l|}{ Keterampilan } & $\begin{array}{c}\text { p- } \\
\text { Value }\end{array}$ \\
\hline & F & $\%$ & $\mathrm{f}$ & $\%$ & \multirow{2}{*}{0,01} \\
\hline Baik & 18 & 56,2 & 1 & 3,1 & \\
\cline { 1 - 5 } Kurang Baik & 7 & 21,9 & 6 & 18,8 & \\
\cline { 1 - 5 } Total & 25 & 78,1 & 7 & 21,9 & \\
\hline
\end{tabular}

Dari tabel 3 diketahui bahwa petugas kesehatan (dokter, perawat) yang berpengetahuan baik dan terampil sebanyak 18 responden $(56,2 \%)$ lebih banyak dibandingkan dengan petugas kesehatan (dokter, perawat) yang berpengetahuan kurang baik dan cukup terampil yaitu 6 responden $(18,8 \%)$.

Hasil uji statistik dengan menggunakan $\mathrm{Chi}$ Square didapatkan hasil $p$ value $0,01<a: 0,05$ ), yang berarti $\mathrm{Ho}$ ditolak $\mathrm{Ha}$ diterima. Dengan demikian ada hubungan bermakna antara pengetahuan dengan keterampilan petugas kesehatan (dokter, perawat) dalam penatalaksanaan primary survey pada pasien dengan penurunan kesadaran di IGD RS Siloam Sriwijaya Palembang, secara statistik terbukti.

\section{DAFTAR PUSTAKA}

Addi Mardi Harnanto,Siti Lestari, 2014.

Peningkatan Kompetensi Primary Survey Melalui Sosialisasi Guidelines Cardiopulmonary Resuscitation Berdasarkan Rekomendasi American Heart Association 2010 Pada Perawat Di RSUD Kota Surakarta. Jurnal Terpadu IImu Kesehatan, Volume 3, No.1, Mei 2014, hlm $35-40$

Arikunto, Suharsimi. 2013. Prosedur Penelitian Suatu Pendekatan Praktik. Jakarta: Rineka Cipta

American Heart Association (AHA), 2010. American College of Surgeons Committee on Trauma, Advance Trauma Life Support (ATLS), ninth edition, 2012

Amin Huda Nurarif, \& HardhiKusuma, 2015. 
Aplikasi asuhan keperawatan berdasarkan diagnose medis\& NANDA (North American Nursing Diagnosis Assiciation) NIC-NOC :jilid 3

Anonym (2011). Undang-Undang RI NO 44 Tahun 2009 Tentang Rumah

Sakit.www.depkes.go.id/downloads/U U_No._44_Th_2009_ttg_Rumah_Sak it.pdf. Diakses pada tanggal 17 Maret 2014.

Agus Riyanto.SKM.M.Kes.2011. Pengolahan dan analisis data kesehatan. Cimahi :NuhaMedika

Boswick, John, A. (2007). Perawatan Gawat Darurat. EGC, Jakarta.

dr.Dian Zamroni,SpJP,dkk, 2016. Bantuan hidup jantun gdasar. Perhimpunan

Dokter Spesialis Kardiovaskuler Jakarta : Edisi 2016

Depkes (2009). UU RI No 36 Tahun 2009 Tentang Kesehatan.www.depkes.go.id/downlo ads/44no-36-th-2009-ttg- kesehatan.pdf. Diakses pada tanggal 17 Maret 2014.

Depkes RI (2009). Kepmenkes RI No 129 Tahun 2008 Tentang Standar Pelayanan Minimal RumahSakit.

www.slideshare.net/f1smed/kepmenke sno129 tahun2008 standar pelayanan mnimal RS. Dinkses pada tanggal 18 Maret 2014.

Deni zulfiana. 2077. Faktor-Faktor Yang Berhubungan Dengan Pengetahuan dokter Dan Perawat Tentang Penatalaksanaan Primary Survey Pada Pasien Penurunan Kesadaran Di IGD RS Siloam Sriwijaya Palembang Tahun 2017 . Skripsi. STIK Siti Khadijah Palembang

Dahlan, M.S. 2011. Statistik Untuk Kedokteran dan Kesehatan. Jakarta: Salemba Medika.

Lindawati F.Tampubolon, Ledy Gresia Sihotang, 2014."Hubungan Pelatihan Primary Survey Dengan Perilaku Perawat Dalam Penanganan Trauma Di Ruangan Instalasi Gawat Darurat Rumah Sakit Santa Elisabeth Medan".Skripsi.Medan: Staff Pengajar ST Ikes Santa Elisabeth

Musliha (2010). Keperawatan Gawat Darurat. Nuha Medika, Yogyakarta.

Notoadmojo (2007). Nursalam, 2013. Metodologi penelitian ilmu keperawatan : edisi ke 3

Notoatmojo, Soekidjo. 2012. Metodologi Penelitian Kesehatan. Jakarta :Rineka Cipta

Sylvia A.Price and Lorraine M.Wilson, 2006 Patofisiologi, konsep klinis proses proses penyakit, edisi ke 6, EGC 2006 